\title{
Intra-specific brood parasitism revealed by DNA micro-satellite analyses in a sub-oscine bird, the vermilion flycatcher
}

\author{
Parasitismo intraespecífico revelado mediante análisis de microsatélites de ADN \\ en un ave suboscina, el cardenalito o saca tu real
}

\begin{abstract}
ALEJANDRO A. RÍOS-CHELÉN ${ }^{1 *}$, JEFFERSON A. GRAVES ${ }^{2}$, ROXANA TORRES ${ }^{1}$, MIGUEL SERRANO-PINTO ${ }^{1}$, LILIANA D'ALBA ${ }^{1,3} \&$ CONSTANTINO MACÍAS GARCÍA ${ }^{1}$
\end{abstract}

\footnotetext{
${ }^{1}$ Departamento de Ecología Evolutiva, Instituto de Ecología, Universidad Nacional Autónoma de México, AP 70-275, CP 04510, México Distrito Federal, México

${ }^{2}$ School of Biology, University of St. Andrews, KY169TS, Scotland, United Kingdom

${ }^{3}$ IBLS, Division of Environmental \& Evolutionary Biology, University of Glasgow, Scotland, United Kingdom;

*e-mail for correspondence: aarios@miranda.ecologia.unam.mx
}

\begin{abstract}
Extra-pair reproduction is known to occur in many avian species. However, among passerines, the majority of studies on extra-pair reproduction have been carried out in oscine birds from temperate regions. Conversely, sub-oscines species, and particularly, species that inhabit tropical regions, have been studied to a much lesser extent. Given that a majority of avian species live in the tropics, it is important to study more tropical and sub-oscine species to have a more accurate picture of the rates of extra-pair reproduction among passerines, and a better understanding of the adaptive function of extra-pair reproduction in birds. Tropical species differ from temperate species in several ecological and life history traits, that may influence the occurrence of different modes of extra-pair reproduction and their prevalence. In this study we asked whether extra-pair reproduction occur in a sexually dimorphic and socially monogamous sub-oscine, the vermilion flycatcher (Pyrocephalus rubinus). We report cases of extra-pair paternity, extra-pair maternity and intra-specific brood parasitism, and discuss our results in the view of other studies with passerines.
\end{abstract}

Key words: extra-pair reproduction, vermilion flycatcher, Pyrocephalus rubinus, sub-oscine, intra-specific brood parasitism.

\section{RESUMEN}

Se sabe que la reproducción extrapareja ocurre en muchas especies de aves. Sin embargo, entre paserinos, la mayoría de los estudios se han llevado a cabo en aves oscinas de regiones templadas. Por el contrario, las especies suboscinas, y en particular las especies que habitan regiones tropicales, se han estudiado mucho menos. Por lo tanto, es importante estudiar más especies tropicales y suboscinas para tener una visión más acertada de las tasas de reproducción extrapareja en paserinos y un mejor entendimiento de la función adaptativa de la reproducción extrapareja en aves. Las especies tropicales difieren de las especies que habitan regiones templadas en diversos rasgos ecológicos y de historia de vida, que podrían influir en las tasas de ocurrencia de diferentes modos de reproducción extrapareja. En este estudio nos preguntamos si ocurre o no la reproducción extrapareja en el cardenalito o saca tu real (Pyrocephalus rubinus), un suboscino sexualmente dimórfico y socialmente monógamo. Reportamos casos de paternidad extrapareja, maternidad extrapareja y parasitismo intraespecífico, y discutimos nuestros resultados bajo la luz de otros estudios en paserinos.

Palabras clave: reproducción extrapareja, Saca tu real, Pyrocephalus rubinus, suboscino, parasitismo intraespecífico.

\section{INTRODUCTION}

Although it is accepted that a majority of passerine birds are socially monogamous, there is increasing evidence that individuals seek extra-pair matings in the overwhelming majority of passerine species studied so far (reviewed in Griffith et al. 2002). Understanding the significance of the great inter-specific variation in the frequency of 
extra-pair paternity (EPP; $0->70 \%$ between species, Møller \& Birkhead 1994) has become a paramount challenge for behavioural ecologists. Yet, after 20 years of studies and accumulating information on the topic, a general and convincing explanation of the observed inter-specific variation in rates of EPP remains elusive.

Among passerines, most studies on extrapair reproduction (EPR) have been carried out in oscine birds from temperate regions, while sub-oscines and tropical species have been studied to a much lesser extent (Stutchbury \& Morton 2001, Griffith et al. 2002). Sub-oscine species differ from their "sister group" (i.e., oscine or songbirds) in some life history and ecological traits that may influence the mechanism and occurrence of extra-pair reproduction: (1) Ontogeny of song production. Evidence indicates that while songbirds learn to sing, sub-oscines do not (i.e., song production in sub-oscines seem to be more determined by an "endogenous" mechanism; review in Kroodsma 1982). The process of learning to sing has been related to the evolution of complex and elaborate songs in oscines (Kroodsma 1982), and therefore relatively less variable and less complex songs could be expected in sub-oscines. Regarding oscines, different aspects of song structure (e.g., the presence of particular phrases in canaries Serinu canaries, Vallet \& Kreuzer 1995, Vallet et al. 1998) have been related to mate preferences, and song repertoire size has been shown to play a key role in determining extra-pair reproductive success (Hasselquist et al. 1996); however, it is not known how, or even whether, any aspects of song structure in sub-oscines may influence the occurrence of EPR. (2) Geographic distribution. While suboscines occur mostly in their inferred geographical areas of origin, oscines have undergone extensive geographical dispersal from Australasia (Barker et al. 2004), resulting in a current worldwide distribution. This makes oscines, in terms of radiation, one of the most successful groups of birds. On the other hand, sub-oscines do not occur in Europe and are more widely distributed in tropical regions of the New World, Africa and Asia (Ericson et al. 2003, Moyle et al. 2006), accounting for more than $30 \%$ of the world's richest avifauna, which occurs in the
Neotropics (Chesser 2004). This is important because differences in ecological conditions between tropical and temperate regions (e.g., seasonality, Stutchbury \& Morton 2001) may relate to different rates of EPP between species.

Because oscine species from temperate regions of the world have been extensively studied and tropical species have not, Stutchbury \& Morton (2001) suggested that there is a "temperate zone bias" in our knowledge of avian mating systems. In fact, their book "Behavioral ecology of tropical birds" can be seen as a "call to arms" to focus our efforts on studying more tropical bird species. Because a larger diversity of bird species occur in the tropics than in temperate zones (Stutchbury \& Morton 2001), what we may think as the "rule" that appears to be emerging in many passerine mating systems, that is, based on temperate species studies (i.e., socially, but not genetically, monogamous systems), may be the "exception". Clearly more studies in tropical species (and among them sub-oscines) are needed to verify if this is true or not.

Another form of EPR that may be related to different ecological conditions is intra-specific brood parasitism (ISBP, Reyer et al. 1997). This mode of EPR occurs when a female lays eggs in the nest of a conspecific host female, and the host female incubates and raises the young (Andersson \& Åhlund 2001). Among the several forms of extra-pair reproduction, ISBP has been studied to a lesser extent (Birkhead et al. 1990), and has been considered to occur rarely in birds (Reyer et al. 1997). However, the rate of ISBP can greatly differ within and among avian species. For instance, the proportion of nest parasitized has been estimated from 5-46\% for some populations of starlings (Sturnus vulgaris) and up to more than $50 \%$ for some species of ducks (review in Davis 1988). It is not known whether different rates of ISBP are related in some way to seasonality, but if ISBP is based in some degree on the probability of finding host nests, then we could expect higher rates of ISBP in temperate regions, where birds breed in a shorter period of time in comparison with tropical species, and therefore may have a higher probability of finding host nests during the breeding period. 
Here, we studied the reproductive system of the vermilion flycatcher, Pyrocephalus rubinus (Tyrannidae, Boddaert, 1783), in a population of central Mexico. The vermilion flycatcher is a socially monogamous and sexually dichromatic sub-oscine. Sexual dimorphism is also related to the singing behaviour since females do not usually sing. Females build the nests and incubate the clutch of one to three eggs (usually three) and both parents feed the young (Díaz Ríos 2002, A. Ríos-Chelén personal observations). We investigated whether or not the reproductive system of the vermilion flycatcher includes the occurrences of EPR or, conversely, whether this species can be considered genetically monogamous.

\section{MATERIAL AND METHODS}

\section{Study area}

We studied a population of vermilion flycatchers ( $n=$ approximately 24 pairs) located in the forest of San Diego Metepec $\left(19^{\circ} 17.97 \mathrm{~N}, 98^{\circ} 14.60 \mathrm{~W}\right)$, Tlaxcala, Mexico, where blood samples were collected in 2001 and 2003. The study site is a mixture of native Pinus spp. and introduced Eucalyptus spp. forest and open areas. Most vermilion flycatchers in this population are migrants, with the exception of two males that were year round residents. The reproductive season for this population starts around February, when most migrant males begin to establish territories, and finishes around late July or early August, by which time most males have departed for the non-breeding grounds.

\section{DNA extraction and PCR products}

Adults were captured with mist nests and baited spring traps and colour ringed. Chicks were collected at their nests when 8 days old and returned to their nest once their blood was obtained. Blood samples (70-240 $\mu \mathrm{L})$ were taken by puncturing the brachial vein, and collecting the blood with capillary tubes. Samples were stored in lysis buffer at $4{ }^{\circ} \mathrm{C}$ until DNA was extracted.

DNA was obtained by phenol-chloroform extraction and ethanol precipitation (Sambrook et al. 1989). We used three micro-satellites markers (micro-satellites Py448, Py274, and Py390) developed for this species (see below for method). Approximately 3-10 ng of genomic DNA were amplified in $10 \mu \mathrm{L}$ PCR reactions containing $1 \mathrm{x}$ buffer, $1.5 \mathrm{mM} \mathrm{MgCl} 2$ (for micro-satellites Py274 and Py390) or 1.0 $\mathrm{mM} \mathrm{MgCl} 2$ (for micro-satellite Py448), $10 \mathrm{pM}$ of each primer, $0.5 \mathrm{U}$ of $\mathrm{Taq}$ and made up to volume with sterile distilled water. The reactions were denatured at $95{ }^{\circ} \mathrm{C}$ for $4 \mathrm{~min}$ followed by 30 cycles of $95{ }^{\circ} \mathrm{C}$ for $10 \mathrm{sec}$, primer-specific annealing temperatures $(60,54$ or $56^{\circ} \mathrm{C}$ for micro-satellites Py448, Py390 and Py274 respectively) for $45 \mathrm{sec}, 72{ }^{\circ} \mathrm{C}$ for 45 seconds and final elongation at $72^{\circ} \mathrm{C}$ for $5 \mathrm{~min}$. PCR products were separated on $6 \%$ polyacrylamyde gels, visualized by silver staining, and allele lengths scored by visual inspection using a 10 base pair DNA ladder (Invitrogen) as a reference.

\section{Development of micro-satellites}

A microsatellite-enriched genomic library was developed using modifications to the protocol of Hamilton et al. (1999). Genomic DNA was extracted from whole blood, digested with Mbo I (Promega) and hybridized with a biotinilated $(\mathrm{CA})_{24}$ oligonucleotide (Operon) to capture single tandem repeats (STRs) of (CA)n. These fragments were cloned into a Bam HI site in pUC18 plasmid and used for transformation by heat shock of Epicurean Supercompetent $E$. coli. XL-1 (Stratagen). One hundred and 93 colonies were grown on a Nylon membrane (Electran $\left.+{ }^{\circledR}, \mathrm{BDH}\right)$ and their DNA was UV cross-linked. The membrane was hybridized with a $\mathrm{P}^{32}$ 5' end-labelled $(\mathrm{CA})_{22}$ oligonucleotide and used for autoradiography. From a total of 99 colonies, plasmids of 28 positive colonies were extracted using Perfectprep kit (Eppendorf) and their inserts were sequenced with universal -23M13 primers in an automated ABI Prism 377 sequencer.

For each sequence, primers were designed using Primer 3 program (Rozen \& Skaletzky 2000). For each primer set, curves of $\mathrm{Mg}^{++}$ concentration and $\mathrm{T}_{\text {annealing }}$ were performed to optimise amplification conditions (those yielding no extra-bands and sharp products; see Table 1 for characterization of microsatellites). 


\title{
TABLE 1
}

Characterization of Pyrocephalus rubinus micro-satellite loci. For locus Py448 there was no (100 $\%$ ) clear motif (sequence added in GenBank). See "DNA extraction" for primer specific annealing temperatures and primer specific $\mathrm{MgCl}_{2}$ concentration for PCR. Accession numbers are for the sequences, which have been deposited in GenBank

\begin{abstract}
Caracterización de microsatélites de Pyrocephalus rubinus. Para el locus Py448 no hubo un motivo (100 \%) claro (secuencia agregada en GenBank). Ver "DNA extraction" para información sobre las temperaturas y concentraciones de $\mathrm{MgCl}_{2}$ específicas a cada primer, para realizar el PCR. Los números de acceso son para las secuencias depositadas en
\end{abstract} GenBank

\begin{tabular}{ccccc}
\hline Locus & Accession number & Repeat motif & Primer sequence $\left(5^{\prime}\right.$-3 $\left.^{\prime}\right)$ & Alelle range $(\mathrm{bp})$ \\
\hline Py274 & DQ834920 & $(\mathrm{TG})_{10} \mathrm{~N}_{60}(\mathrm{CT})_{2}(\mathrm{GT})_{7}$ & AGGCATGATGAGGAACTCCA & $245-450$ \\
& & CTCCCAAGGGAGGATGTCTA & \\
Py390 & DQ834919 & $(\mathrm{CA})_{3} \mathrm{~N}_{8}(\mathrm{CA})_{4} \mathrm{GA}$ & CACACTCACACTCACGCTCA & $192-205$ \\
& & $(\mathrm{CA})_{4} \mathrm{~N}_{12}(\mathrm{AC})_{8}$ & GTGTGTGCACGAACACCTG & $250-332$ \\
Py448 & DQ834918 & & CACTGTCACACAAAATCACACG & 2 \\
\end{tabular}

\section{DNA analysis}

In 2001 six families were genotyped. From these families we obtained blood samples of all six males, three of the females and all but two of the 20 chicks. For this year we also obtained blood sample from five more adults in the population (two males, three females). In 2003, we sampled eight families, obtaining DNA from all eight males, five of the females and all 21 chicks. For this year we also obtained blood samples from eight more adults in the population (five males, three females). All adult individuals (14 in 2001 and 21 in 2003) were used to obtain allele frequencies (Table 2). We ran the PCR products using the three microsatellite markers from the putative father, mother and offspring in adjacent columns to facilitate the comparison of allele bands between family members. We considered a chick to be the result of EPR if at least one allele (band) was not shared between the nestling and either of the putative parents. The micro-satellites had relatively low numbers of alleles in this population (Table 2). This relatively low variability, plus the fact that not all adult birds were sampled, made it impossible for us to assign genetic parentage. However, we were able to identify chicks that had a different genetic father or mother from the adult on the nest. To lower the risk of typing errors and misreading some alleles, along with positive and negative controls we ran each gel with individuals that were formerly typed and used in other polyacrylamyde gels, and thus their bands served as a reference for new individuals.

\section{TABLE 2}

Data on micro-satellite allele frequencies. Data from 14 and 21 adult individuals sampled in years 2001 and 2003 respectively. Note that in year 2003 our sample lacked allele 298 from locus Py448

Datos sobre frecuencias alélicas de microsatélites. Datos de 14 y 21 individuos adultos muestreados en los años 2001 y 2003 respectivamente. El alelo 298 del locus Py448 no se encontró en nuestra muestra del año 2003

\begin{tabular}{lccc}
\hline Locus & Allele $(\mathrm{bp})$ & Year 2001 & Year 2003 \\
\hline Py448 & 250 & 0.2143 & 0.0238 \\
& 260 & 0.3214 & 0.5238 \\
& 298 & 0.0714 & - \\
& 318 & 0.1429 & 0.2143 \\
& 322 & 0.1429 & 0.1667 \\
& 330 & 0.0357 & 0.0476 \\
& 332 & 0.0714 & 0.0238 \\
Py274 & 245 & 0.3571 & 0.4048 \\
& 255 & 0.3929 & 0.3810 \\
& 312 & 0.2143 & 0.0714 \\
& 450 & 0.0357 & 0.1429 \\
Py390 & 202 & 0.8214 & 0.9524 \\
& 205 & 0.1786 & 0.0476 \\
\hline
\end{tabular}


To obtain basic statistics such as observed and expected heterozygocity, and to verify if our loci were under Hardy-Weinberg equilibrium, we used Cervus software (Marshall et al. 1998) and Genepop software (Raymund \& Rousset 1995), respectively.

\section{RESULTS}

Information on allele frequencies and individual genotypes are given in Table 2 and 4 respectively. Table 3 shows that locus Py274 was not under Hardy-Weinberg equilibrium, presenting a statistically significant heterozygote deficit both in 2001 and 2003.

Heterozygote deficit could be the result of several factors, for instance endogamy or presence of null alleles; this latter possibility is a potential source of bias in paternity analyses (Dakin \& Avise 2004). Therefore, to take into account this possibility, we re-analysed our data using ML-Relate software (Kalinowski et al. 2006), for this software can take into account the presence of null alleles when estimating maximum-likelihood relationships between individuals. To this end, we tested in ML-Relate the hypothesis that putative parents had a Parent-Offspring relationship with their putative offspring (putative relationship) against the alternative relationship, that is, that these putative parents are unrelated to their putative offspring. For these analyses we used 1000 simulations and, in a first try, we set up a $\mathrm{P}$ value of $<0.05$ as a criterion to decide if the putative relationship fits the data significantly better than the alternative relationship. These analyses showed that in 2001, $100 \%$ families contained extra-pair offspring and $94 \%$ chicks in the sample had extra-pair parentage. In 2003, $87 \%$ families had extra-pair parentage and 80 $\%$ chicks resulted of extra-pair reproduction. It is very likely that given the sparseness of our data, the frequencies of EPR when using a $\mathrm{P}<$ 0.05 were overestimated. For this reason, we re-analysed our data, but this time using a more conservative approach, that is, considering a $\mathrm{P}$ $<0.2$. In other words, this would give us at least an $80 \%$ probability that the putative relationship fits the data better than the alternative relationship.

Because we are not certain that the observed heterozygote deficit is due the presence of null alleles, we still kept our original way of analysing our data, that is, by visual inspection of shared and non-shared bands. Hence, both ways of data analyses, can give us a range of incidence of extra-pair reproduction, encompassing both the possibility that the observed heterozygote deficit is or is not a by product of the presence of null alleles.

Descriptive statistics of micro-satellite loci. $\mathrm{H}_{\mathrm{O}}=$ observed heterozygocity, $\mathrm{H}_{\mathrm{E}}=$ expected heterocygocity. Estimation of P values in HW (to test for Hardy Weinberg equilibrium) and Hdef (to test for heterozygote deficit) by the Markov chain method in Genepop software. Statistically significant $\mathrm{P}$ values are in bold. See "DNA extraction and PCR products" for primer specific annealing temperatures and primer specific $\mathrm{MgCl}_{2}$ concentration for PCR

Estadística descriptiva de loci de microsatélites. $\mathrm{H}_{\mathrm{O}}=$ heterogocidad observada, $\mathrm{H}_{\mathrm{E}}=$ heterogocidad esperada. Se estimaron los valores de P en HW (para probar equilibrio de Hardy Weinberg) y Hdef (para probar si hay deficiencia de

heterocigotos) por medio del método de cadena de Markov en el programa Genepop. Valores de P estadísticamente significativos se muestran en negrilla. Ver "DNA extraction and PCR products" para información sobre las temperaturas y concentraciones de $\mathrm{MgCl}_{2}$ específicas a cada primer, para realizar el PCR

\begin{tabular}{|c|c|c|c|c|c|c|c|c|}
\hline \multirow[t]{2}{*}{ Locus } & \multicolumn{4}{|c|}{$\begin{array}{c}2001 \\
(\mathrm{n}=14)\end{array}$} & \multicolumn{4}{|c|}{$\begin{array}{c}2003 \\
(\mathrm{n}=21)\end{array}$} \\
\hline & $\mathrm{H}_{\mathrm{O}}$ & $\mathrm{H}_{\mathrm{E}}$ & HW & Hdef & $\mathrm{H}_{\mathrm{O}}$ & $\mathrm{H}_{\mathrm{E}}$ & HW & Hdef \\
\hline Py 274 & 0.429 & 0.696 & 0.004 & 0.007 & 0.429 & 0.682 & 0.017 & 0.0007 \\
\hline Py390 & 0.357 & 0.304 & 1.000 & 1.000 & 0.095 & 0.093 & 1.000 & 1.000 \\
\hline Py 448 & 1.000 & 0.828 & 0.764 & 1.000 & 0.762 & 0.664 & 0.391 & 0.656 \\
\hline
\end{tabular}




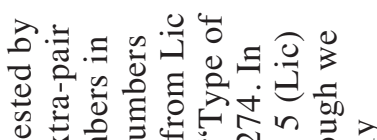

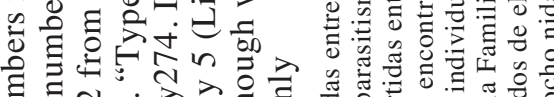
ox $\begin{aligned} & x \\ & 0\end{aligned}$

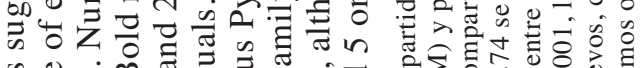
๘

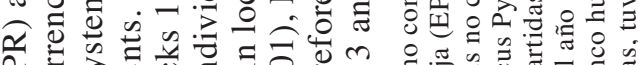

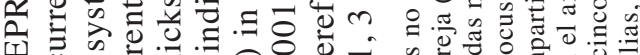

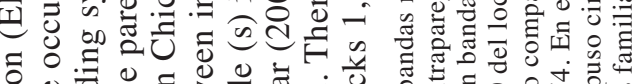

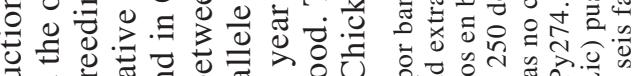

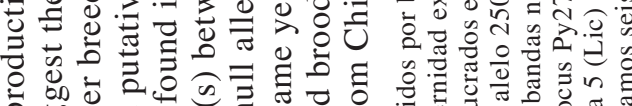

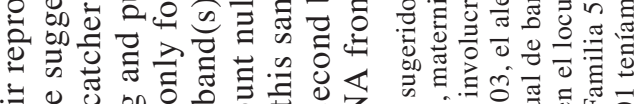
光.

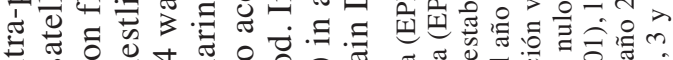

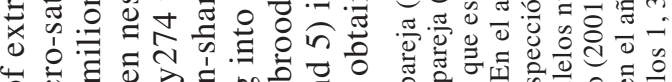

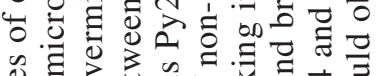

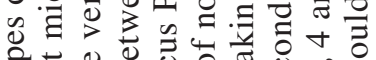

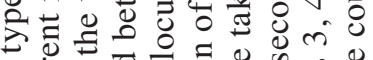

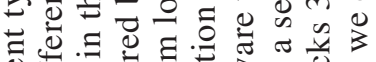

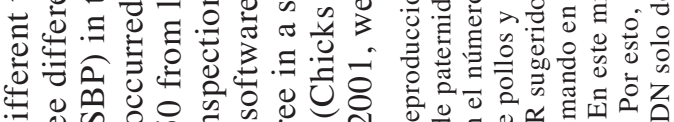

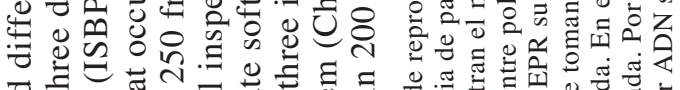
马

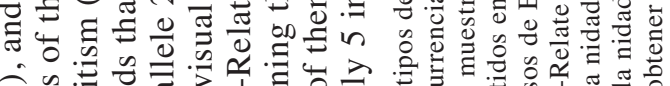

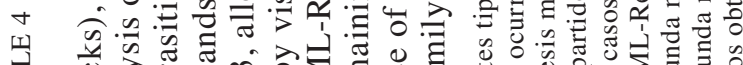

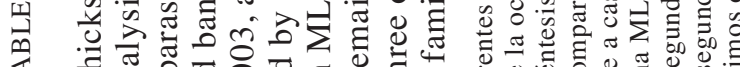

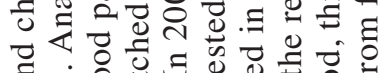

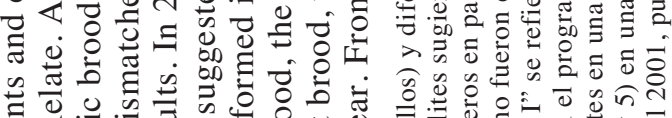

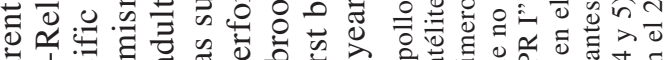

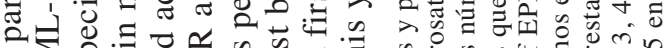
थ之

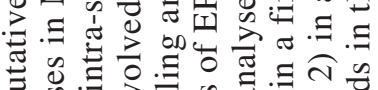

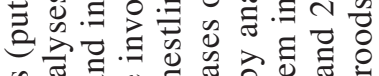

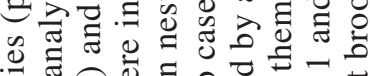

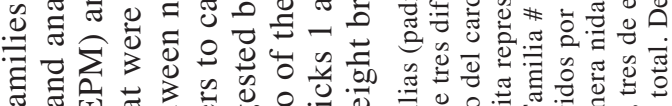

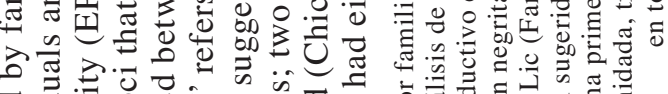

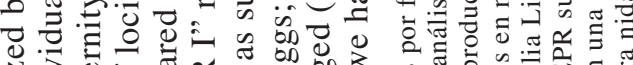
.

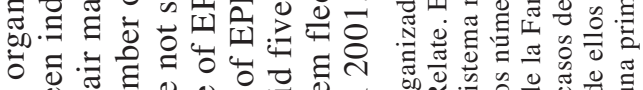
tᄒ

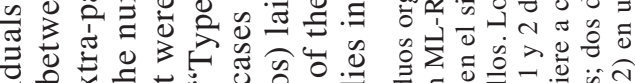

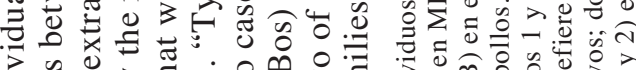

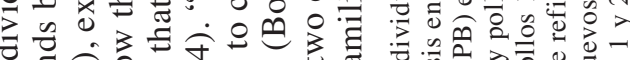

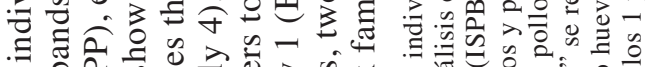

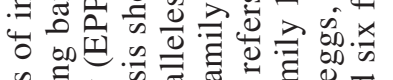

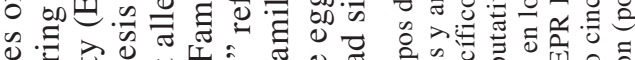

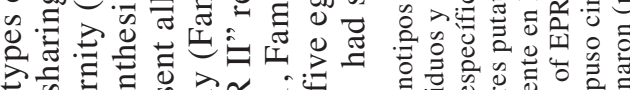

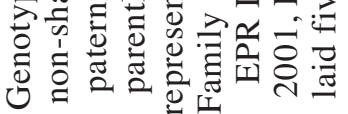

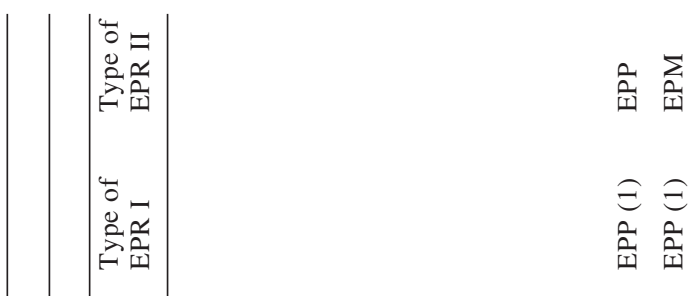

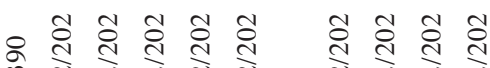

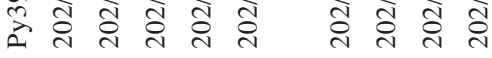

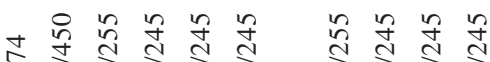

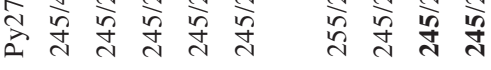

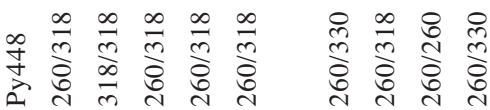

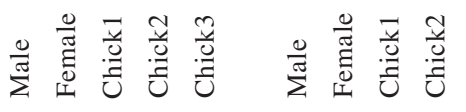

$\bar{s}$

恶

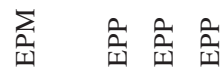

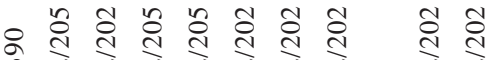

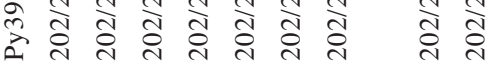

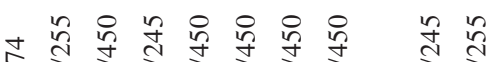

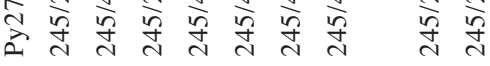

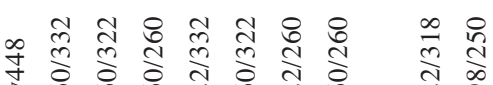
๘

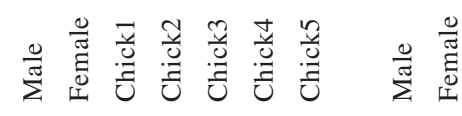

$\stackrel{\infty}{\infty}$ 


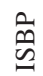

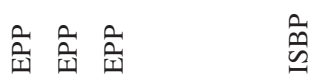

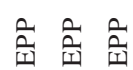

$\Xi$
$\stackrel{\overline{0}}{\underline{n}}$

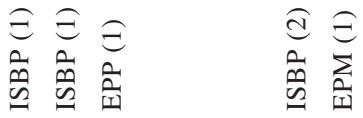

辛

สิ สิ สิ สิ สิ

สิ สิ สิ ฮิ

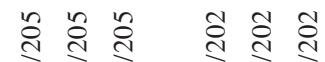

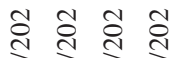

ते ते ते ते ते ते ते

ते त्वे त्वे ते ते ते

वे वें वे वे वे वे

ते त्वे त्वे ते ते

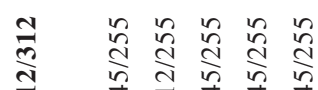

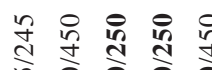

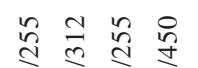

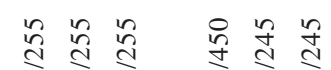

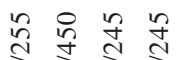

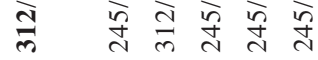

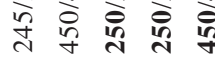

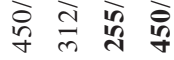

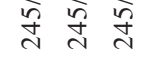

客客守

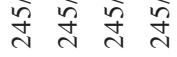

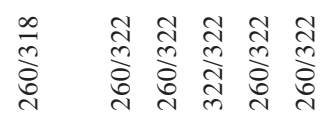

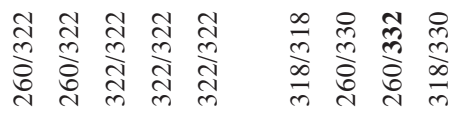

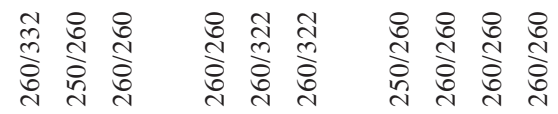

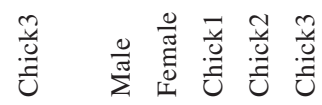

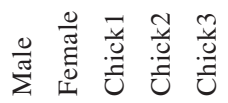

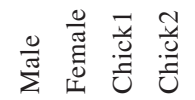

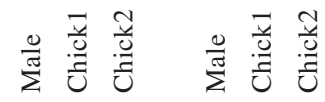

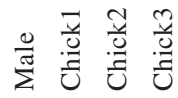

恿

$\stackrel{9}{g}$

$\bar{s}$
of
in

$\stackrel{\circ}{\circ}$

$\stackrel{\text { ㄷำ }}{\sim}$

$\sum_{\infty}^{\infty}$

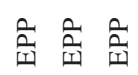

$\sum_{\text {ît }}$

䲡

藏

$\widehat{d} € €$

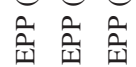

$\underset{\substack{0 \\ \text { int }}}{\widehat{0}}$

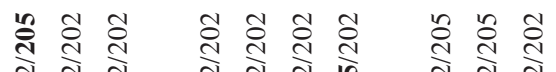

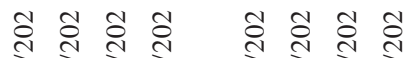

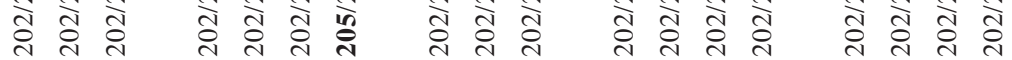

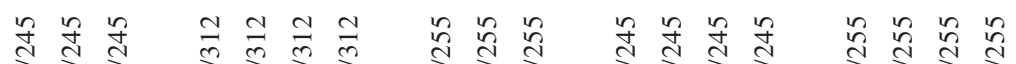

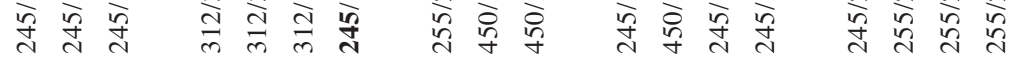

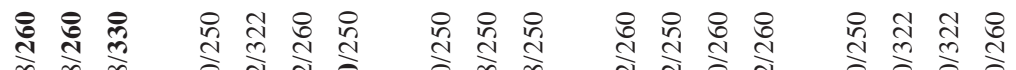

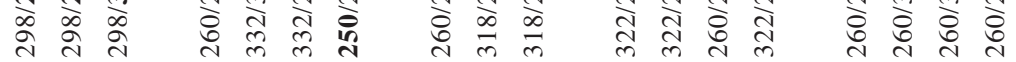

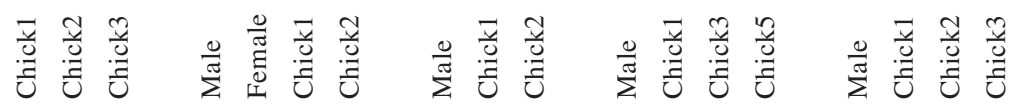

桨

tis

$\frac{0}{3}$

$\sum_{0}^{t}$ 
$M L$-Relate results (taking into account the possibility of null alleles)

In 2001, six out of eight broods $(75.0 \%)$ contained extra-pair offspring. Among these eight broods, EPP was found in four $(50.0 \%)$, and extra-pair maternity (EPM) in two (25.0 $\%)$. In terms of all chicks in the sample $(\mathrm{n}=$ $18)$, nine $(50.0 \%)$ were probably the result of EPP, and two (11.1\%) the result of EPM. Overall, 11 chicks $(61.1 \%)$ were extra-pair offspring. In 2003, four out of eight broods $(50.0 \%)$ contained extra-pair offspring. From these eight broods, three $(37.5 \%)$ contained EPP chicks, one (12.5\%) contained an EPM chick, and two $(25.0 \%)$ contained a chick that probably resulted from ISBP. In terms of chicks in the whole sample $(\mathrm{n}=21)$, seven $(33.3 \%)$ were the result of EPP, one $(4.7 \%)$ was the result of EPM, and two (9.5\%) the result of ISBP. Hence, 10 chicks $(47.6 \%)$ had extra-pair parentage.

\section{Visual inspection results}

In 2001 two out of eight broods (25.0\%) contained at least one chick that resulted from extra-pair reproduction. In one $(12.5 \%)$ of those broods, all chicks $(n=3)$ presumably resulted from EPP (in all of them, one allele from the father could not be matched to the male on the nest). In the other brood (12.5\%), there was EPM. In this brood one chick was not the offspring of the female on the nest, but was probably the offspring of the male (i.e., we had no evidence to state that it was not: the genotype of the nestling shared at least one allele with its social father at all three loci). In terms of all nestlings in the sample $(n=18)$, three chicks $(16.6 \%)$ resulted from EPP, and one $(5.5 \%)$ from EPM. Overall, four out of 18 chicks $(22.2 \%)$ probably resulted from extrapair reproduction (Table 5). In 2003, three out of eight broods $(37.5 \%)$ were found to have extra-pair offspring. Among these eight nests, EPP was found in two of them $(25.0 \%)$, EPM in one of them $(12.5 \%)$, and ISBP in three of them $(37.5 \%)$. In terms of number of chicks in the whole sample $(\mathrm{n}=21)$, three $(14.2 \%)$ were not the offspring of the male on the nest (i.e., extra-pair paternity), and four $(19.0 \%)$ were the result of ISBP. As in 2001, and considering all 21 chicks in the sample, we found one chick $(4.7 \%)$ whose mother was not the female on the nest, but whose father was probably the male at the nest (i.e., EPM or quasi-parasitism, Yezerinac 1995). Hence, eight chicks out of 21 $(38.0 \%)$ had extra-pair parentage.

Table 5 summarizes both the "visual inspection" and the "ML-Relate" results.

TABLE 5

Percentage of broods and chicks that were the result of different modes of extra-pair reproduction in 2001 and 2003. EPP = extra-pair paternity, EPM = extra-pair maternity, ISBP = intra-specific brood parasitism, EPR = extra-pair reproduction. Results from visual inspection and from MR-Relate are shown for comparison

Porcentaje de nidadas y pollos que fueron resultado de diferentes modos de reproducción extrapareja en los años 2001 y 2003. $\mathrm{EPP}=$ paternidad extrapareja, $\mathrm{EPM}=$ maternidad extrapareja, $\mathrm{ISBP}=$ parasitismo intraespecífico, $\mathrm{EPR}=$ reproducción extrapareja. Se muestran resultados de inspección visual y de EM-Relate para comparar

\begin{tabular}{|c|c|c|c|c|c|}
\hline \multirow[t]{3}{*}{ Variable } & \multirow[t]{3}{*}{ Mode } & \multicolumn{4}{|c|}{ Year } \\
\hline & & \multicolumn{2}{|c|}{2001} & \multicolumn{2}{|c|}{2003} \\
\hline & & Visual inspection & ML-Relate & Visual inspection & ML-Relate \\
\hline \multirow[t]{4}{*}{ Broods $(\%)$} & EPP & 12.5 & 50.0 & 25.0 & 37.5 \\
\hline & EPM & 12.5 & 25.0 & 12.5 & 12.5 \\
\hline & ISBP & 0.0 & 0.0 & 37.5 & 25.0 \\
\hline & EPR & 25.0 & 75.0 & 37.5 & 50.0 \\
\hline \multirow[t]{4}{*}{ Chicks (\%) } & EPP & 16.6 & 50.0 & 14.2 & 33.3 \\
\hline & EPM & 5.5 & 11.1 & 4.7 & 4.7 \\
\hline & ISBP & 0.0 & 0.0 & 19.0 & 9.5 \\
\hline & EPR & 22.2 & 61.1 & 38.0 & 47.6 \\
\hline
\end{tabular}




\section{DISCUSSION}

Despite our small sample size, we found evidence that the mating system of the vermilion flycatcher is far more complicated than simple monogamy. Our results point to cases of extra-pair paternity, extra-pair maternity (quasi-parasitism) and intra-specific brood parasitism.

The most striking possible effect of null alleles in our data might have been an underestimation of EPP and EPM in 2001, and an overestimation of ISBP combined with an underestimation of EPP in 2003 (see Table 5). However, since null alleles are not the only possible source of heterozygote deficit, it may be better to take those results as an upper boundary of extra-pair reproduction in this species, rather than accepting that the possible effects of null alleles provide an accurate picture of extra pair parentage (see below). Besides null alleles, other potential sources of bias in our results would be a high mutation rate, and having misread some alleles in our gels. Based on studies made with Drosophila melanogaster and humans, mutation rates in micro-satellites have been considered to be relatively low (i.e., 10-2-10-4; DeWoody \& Avise 2000, Bailey et al. 2007). This, with the relatively low numbers of alleles reported for each micro-satellite in this study combined with the relatively large number of chicks presenting an extra band does not point to mutation as a likely source of bias in our results. It is also unlikely that we might have misread some alleles. This is because the use of a positive control (i.e., from a plasmid) aided us in determining the gel area where we should expect to find our micro-satellite bands. The use of other individuals as positive controls (i.e., alleles coming from individuals that had already been run in previous gels) also provided a reference for new individual's alleles. Moreover, mismatched bands were very different in size (372 bp, and 5-200 bp for years 2001 and 2003 respectively; Table 2) which made identification of mismatched bands a relatively easy task. Nevertheless, the rates of EPR found in this study should be viewed with caution since, in our visual inspection we found that only two out of four (50.0\% for 2001) and one out of eight (12.5\% for 2003) extra-pair chicks were found to have a mismatch at more than one locus (Table 4).
Depending on the method used (visual inspection or ML-Relate), extra-pair paternity ranged from $16.6 \%$ to $50.0 \%$ chicks in 2001 and from $14.2 \%$ to $33.3 \%$ chicks in 2003 . Other studies in socially monogamous species have found that on average $11.1 \%$ of offspring and $18.7 \%$ of broods result from extra-pair paternity (Griffiths et al. 2002). However, given the small sample sizes in our study, our results may not be representative of the population as a whole, and thus should serve more to describe the occurrence of EPR in the vermilion flycatcher, rather than to compare it with other avian populations. Some studies on oscine birds have shown a relation between male phenotype (i.e., song repertoire size) and EPP, whereby females may seek genetic benefits for their offspring (Hasselquist et al. 1996). Extra-pair paternity has been shown to occur at relatively high levels in a few suboscines. For instance, Woolfenden et al. (2005) reported, for the acadian flycatcher (Empidonax virescens), that $58 \%$ of nests contained extra-pair offspring and $40 \%$ of nestlings were extra-pair young, while Tarof (2001) reported up to $61.9 \%$ of broods having extra-pair offspring in the least flycatcher (Empidonax minimus). This relatively high incidence of extra-pair offspring in the least flycatcher may be explained in part by the "open mating system" characteristic of this species, whereby clusters of individuals can be visited by individuals from other sites trough out the breeding season (Kasumovic et al. 2003). On the other hand, Dolan et al. (2007), studying the suboscine eastern kingbird (Tyrannus tyrannus), found that those males singing early in the dawn chorus were more successful in increasing their reproductive success via extra-pair paternity, which reached a level of $61 \%$ of nests and $47 \%$ of offspring. It is still not known what aspects of male phenotype might promote extra-pair paternity in the vermilion flycatcher.

Since we could not assign parentage, we cannot discard the possibility that cases where we found EPP or EPM are in fact instances of ISBP. Because of this, we focus the remainder of our discussion on the occurrence of this mode of extra-pair reproduction.

This is the first time that ISBP has been reported in the Vermilion Flycatcher. ISBP has been reported in other species (Birkhead et al. 1990, Petrie \& Møller 1991, Jackson 1993, McRae \& Burke 1996, Lyon 2003), with 
relatively low frequencies of occurrence in some (e.g., zebra finch, Taeniopygia guttata: $10.9 \%$ of offspring, Birkhead et al. 1990; the sand martin, Riparia riparia: $1.8 \%$ of offspring, Alves \& Bryant 1998) and relatively high in others (e.g., nests parasitized: up to 46 $\%$ in starlings Sturnus vulgaris, up to $24 \%$ in cliff swallows Hirundo pyrrhonota, up to $31 \%$ in swallows H. rustica; review in Davies 1988, and perhaps up to $39 \%$ of offspring in the eastern kingbird, McKitrick 1990). However, in this latter case, it could not be discerned whether these extra-pair reproduction events where result of ISBP, quasi-parasitism or both. Several hypotheses have been brought forward to explain the occurrence of ISBP. One possibility is that neither the male nor the female are aware of other female laying egg(s) on their nest. In this hypothesis the social partner gain no benefit from ISBP. In the case of the vermilion flycatcher, this hypothesis seems likely because only females incubate eggs and thus the nest may occasionally be left unattended for relative long periods of time. On the other hand, it is also possible that one or both pair members may obtain some benefits by allowing the parasitic female to lay eggs in the host nest (McRae \& Burke 1996). For example, males may cooperate with parasitic females by letting her lay eggs in their nests in exchange for copulations. If this is the case, we should expect this male to sire some offspring in the parasitic female's own nest or in his own nest (i.e., quasi-parasitism or extra-pair maternity).

We found that in 2003 between $9.5 \%$ and $19.0 \%$ of chicks in our sample was probably the result of ISBP. Regardless of the method used (visual inspection or ML-Relate), we found that in one of the nests where ISBP presumably occurred also occurred a case of extra-pair maternity. While we could not determine whether the mother of this quasiparasitic offspring was the same female that laid the ISBP egg in this nest, this result points to the "in exchange of copulations" hypothesis. However, for the time being this interpretation is speculative and a more detailed study, where paternity and maternity can be assigned, is needed to address this hypothesis.

To conclude, we found evidence that the vermilion flycatcher, although socially monogamous, incur in different modes of extrapair reproduction. This expands our knowledge on the mating system of a suboscine species, a group of passerines that deserves more studies. The observed frequency of EPR in this study underlines the need to conduct further studies to assess which individual attributes (if any), either morphological (e.g., body mass and size, plumage colouration) or behavioural (e.g., song and flight display: Smith 1967, 1970, RíosChelén \& Macías 2004, Ríos Chelén et al. 2005), promote extra-pair reproduction in this sub-oscine species.

\section{ACKNOWLEDGMENTS}

We thank M. Martínez and R. Angélica from the Centro Tlaxcala de Biología de la Conducta, for allowing the use of the laboratory facilities during field work. A. Guillén, C. Espinosa, and C. Ibarra greatly assisted during field work. Two anonymous reviewers greatly improved the quality of a previous version of this paper with their comments and suggestions. We thank M. Rentería who provided invaluable help trough out the laboratory work. Ríos-Chelén thanks S. Kallinowski for his advice with some questions regarding the use of ML-Relate, and $\mathrm{M}$. Améndola for help with Genepop. We thank C. Cordero and $\mathrm{K}$. Renton for sharing with us discussions on this study. AARCH was supported by a CONACyT $\mathrm{PhD}$ and a PAEP (project \#201318) grants and CMG with a UNAM (DGAPA) research grant (PAPIIT IN225799).

\section{LITERATURE CITED}

ALVES SMA \& DM BRYANT (1998) Brood parasitism in the sand martin, Riparia riparia: evidence for two parasitic strategies in a colonial passerine. Animal Behaviour 56: 1323-1331.

ANDERSSON M \& M ÅHLUND (2001) Protein fingerprinting: a new technique reveals extensive conspecific brood parasitism. Ecology 82: 14331442 .

BAILEY NW, C MACÍAS GARCIA \& MG RITCHIE (2007) Beyond the point of no return? A comparison of genetic diversity in captive and wild populations of two nearly extinct species of goodeid fish reveals that one is inbred in the wild. Heredity 98: 360-367.

BARKER FK, A CIBOIS, P SCHIKLER, J FEINSTEIN \& J CRACRAFT (2004) Phylogeny and diversification of the largest avian radiation. Proceedings of the National Academy of Sciences USA 101: 11040-11045.

BIRKHEAD TR, T BURKE, R ZANN, FM HUNTER \& AP 
KRUPA (1990) Extra-pair paternity and intraspecific parasitism in wild zebra finches Taeniopygia guttata, revealed by DNA fingerprinting. Behavioral Ecology and Sociobiology 27: 315-324.

CHESSER RT (2004) Molecular systematics of New World suboscine birds. Molecular Phylogenetics and Evolution 32: 11-24

DAKIN EE \& JC AVISE (2004) Microsatellite null alleles in parentage analysis. Heredity 93: 504-509.

DAVIES N B (1988) Dumping eggs on conspecifics. Nature 331: 19

DEWOODY JA \& JC AVISE (2000) Microsatellite variation in marine, freshwater and anadromous fishes compared with other animals. Journal of Fish Biology 56: 461-473.

DÍAZ RÍOS M (2002) Inversión de machos y hembras en el cuidado parental del mosquero cardenalito Pyrocephalus rubinus. Tesis de Licenciatura, Facultad de Ciencias, Universidad Nacional Autónoma de México, Distrito Federal, México. 49 pp.

DOLAN AC, MT MURPHY, LJ REDMON, K SEXTON \& D DUFFIELD (2007) Extrapair paternity and the opportunity of sexual selection in a socially monogamous passerine. Behavioral Ecology 18: 985-993

ERICSON PGP, M IRESTEDT \& US JOHANSSON (2003) Evolution, biogeography, and patterns of diversification in passerine birds. Journal of Avian Biology 34: 3-15.

GRIFFITH SC, IPF OWENS \& KA THUMAN (2002) Extra pair paternity in birds: a review of interspecific variation and adaptive function. Molecular Ecology 11: 2195-2212.

HAMILTON MB, EL PINCUS, A DI FIORE \& RC FLEISCHER (1999) Universal linker and ligation procedures for construction of genomic DNA libraries enriched for microsatellites. Biotechniques 27: 500-507.

HASSELQUIST D, S BENSCH \& VON T SCHANTZ (1996) Correlation between male song repertoire, extra-pair paternity and offspring survival in the great reed warbler. Nature 381: 229-232.

JACKSON WM (1993) Causes of conspecific nest parasitism in the northern masked weaver. Behavioral Ecology and Sociobiology 32: 119-126.

KALINOWSKI ST, AP WAGNER \& LM TAPER (2006) ML-RELATE: a computer program for maximum likelihood estimation of relatedness and relationship. Molecular Ecology Notes 6: 576-579.

KASUMOVIC MM, LM RATCLIFFE \& PT BOAG (2003) A method to improve confidence in paternity assignment in an open mating system. Canadian Journal of Zoology 81: 2073-2076.

KROODSMA DE (1982) Learning and the ontogeny of sound signals in birds. In: Kroodsma DE, EH Miller \& H Ouellet (eds) Acoustic communication in birds. Song learning and its consequences. Volume 2: 1-23. Academic Press, New York, New York, USA.

LYON BE (2003) Ecological and social constraints on conspecific brood parasitism by nesting female American coots (Fulica americana). Journal of Animal Ecology 72: 47-60.

MARSHALL TC, J SLATE, LEB KRUUK \& JM PEMBERTON (1998) Statistical confidence for likelihood-based paternity inference in natural populations. Molecular Ecology 7:639-655.

McKITRICK CM (1990) Genetic evidence for multiple parentage in eastern kingbirds (Tyrannus tyrannus). Behavioral Ecology and Sociobiology 26: 149-155.

MCRAE SB \& T BURKE (1996) Intraspecific brood parasitism in the moorhen: parentage and parasite-host relationships determined by DNA fingerprinting. Behavioral Ecology and Sociobiology 38: 115-129.

MØLLER AP \& TR BIRKHEAD (1994) The evolution of plumage brightness in birds is related to extrapair paternity. Evolution 48: 1089-1100.

MOYLE RG, RT CHESSER, RO PRUM, P SCHIKLER \& J CRACRAFT (2006) Phylogeny and evolutionary history of Old World suboscine birds (Aves: Eurylaimides). American Museum Novitates 3544: $1-22$.

PETRIE M \& AP MØLLER (1991) Laying eggs in others' nests: intraspecific brood parasitism in birds. Trends in Ecology and Evolution 6: 315-320.

RAYMOND M \& F ROUSSET (1995) GENEPOP (version 1.2): population genetics software for exact tests and ecumenicism. Journal of Heredity 86: 248-249.

REYER H-U, K BOLLMANN, AR SCHLÄPFER, A SCHYMAINDA \& G KLECACK (1997) Ecological determinants of extrapair fertilizations and egg dumping in Alpine water pipits (Anthus spinoletta). Behavioral Ecology 8: 534-543.

RÍOS-CHELÉN A \& C MACÍAS GARCÍA (2004) Flight display song of the vermilion flycatcher. Wilson Bulletin 116: 360-362.

RÍOS CHELÉN A, C MACÍAS GARCÍA \& K RIEBEL (2005) Variation in the song of a sub-oscine, the vermilion flycatcher. Behaviour 142: 1121-1138.

ROZEN S \& HJ SKALETSKY (2000) Primer3 on the WWW for general users and for biologist programmers. In: Krawetz S \& S Misener (eds) Bioinformatics methods and protocols: methods in molecular biology: 365-386. Humana Press, Totowa, New Jersey, USA.

SAMBROOK J, EF FRITSCH \& T MANIATIS (1989) Molecular cloning: a laboratory manual. Cold Spring Harbor, New York, USA.

SMITH WJ (1967) Displays of the vermilion flycatcher (Pyrocephalus rubinus). Condor 69: 601-605.

SMITH WJ (1970) Courtship and territorial displaying in the vermilion flycatcher, Pyrocephalus rubinus. Condor 72: 488-491.

STUTCHBURY BJM \& ES MORTON (2001) Behavioural ecology of tropical birds. Academic Press, London, United Kingdom. 165 pp.

TAROF SA (2001) Spatial dynamics and evolutionary explanations of clustering behaviour in least flycatchers Empidonax minimus. Ph.D. thesis, Queen's University, Kingston, Ontario. Canada.

VALLET E \& M KREUTZER (1995) Female canaries are sexually responsive to special song phrases. Animal Behaviour 49: 1603-1610.

VALLET E, I BEME \& M KREUTZER (1998) Two-notes syllables in canary songs elicit high levels of sexual display. Animal Behaviour 55: 291-297.

WOOLFENDEN BE, BJM STUTCHBURY \& ES MORTON (2005) Male Acadian fycatchers, Empidonax virescens, obtain extrapair fertilizations with distant females. Animal Behaviour 69: 921-929.

YEZERINAC SM, PJ WEATHERHEAD \& PT BOAG (1995) Extra-pair paternity and the opportunity for sexual selection in a socially monogamous bird (Dendroica petechia). Behavioral Ecology and Sociobiology 37: 179-188. 
